\title{
PEMANFAATAN PERPUSTAKAAN DALAM MENINGKATKAN MOTIVASI BELAJAR SISWA KELAS XI MATA PELAJARAN PPKn DI SMA NEGERI 1 MENTEBAH
}

\author{
Dada Suhaida ${ }^{1}$, Erna Octavia ${ }^{2}$, Lady Diana $^{3}$ \\ 1, 2 Program Studi Pendidikan Pancasila dan Kewarganegaraan, IKIP PGRI \\ Pontianak, Pontianak \\ 3SMA Negeri Mentebah \\ ${ }^{1}$ civic.link@yahoo.com \\ erna8649@yahoo.co.id \\ 3ladydiana@gmail.com
}

\begin{abstract}
ABSTRAK
Tujuan penelitian ini adalah "bagaimana pemanfaatan perpustakaan dalam meningkatkan motivasi belajar siswa PPKn", tujuan penelitian ini khusunya ingin memperoleh informasi pada motivasi belajar siswa PPKn dengan memanfaatkan perpustakaan. Metode penelitian kualtitatif dengan bentuk diskriptif, dengan teknik pengumpulan data berupa panduan observasi, panduan wawancara, dan dokumentasi, untuk teknik analisis data yakni, reduksi data, penyajian data, dan penarikan kesimpulan. Hasil penelitian bahwa, motivasi belajar siswa dengan memanfaatkan perpustakaan cukup baik, hal tersebut tergambar dalam aktivitas siswa yang berkunjung ke perpustakaan selalu menggunakan buku dari perpustakaan dalam membantu menyelesaikan tugas-tugas sekolah, dan aktivitas siswa meminjam buku di perpustakaan cukup sering.

Kata kunci: Pemanfaatan Perpustakaan, Motivasi Belajar
\end{abstract}

\begin{abstract}
The purpose of this study is "how to use library to increase motivation in learning to the PPKn students", the purpose of this study is to obtain information on the learning motivation to PPKn students by utilizing the library, the form of student activities by utilizing the library. Quantitative research methods will used as descriptive form, by using data collection techniques in the form of observation guides, interview guides, and documentation, for data analysis techniques, the researcher will use data reduction, data presentation, and drawing conclusions. The results of this study shows that students' motivation to take advantage of the library is quite high, it is illustrated through students activities in visiting library, students use books from the library to help complete course assignments, and borrow books in the library quite often.

Keywords: Library Utilization, Learning Motivation
\end{abstract}




\section{PENDAHULUAN}

Pendidikan merupakan sebuah proses kegiatan yang disengaja Patas input siswa untuk menimbulkan suatu hasil yang diinginkan sesuai tujuan yang ditetapkan sebagai sebuah proses sengaja maka pendidikan harus dievaluasi hasilnya untuk melihat apakah hasil yang dicapai telah sesuai dengan tujuan yang diinginkan dan apakah proses yang dilakukan efektif untuk mencapai hasil yang diinginkan (Purwanto, 2008). Pendidikan melibatkan siswa, guru, metode, tujuan kurikulum, media, sarana prasarana, masyarakat, serta pengguna lulusan.

Menurut Hamdani (2011: 17) pendidikan merupakan interaksi antara guru dan siswa. Pendidikan dalam arti luas merupakan proses pertumbuhan dan sebagai hasil dari interaksi lingkungan sosial dan lingkungan fisik yang berlangsung sepanjang hayat sejak manusia lahir. Pendidikan mempunyai peran yang sangat menentukan bagi perkembangan dan perwujudan dari individu, terutama bagi pembangunan bangsa dan negara. Menurut Barnadib (Purwanto, 2014:20) ilmu pendidikan adalah ilmu yang membicarakan masalah-masalah pendidikan secara umum, menyeluruh dan abstrak, disamping pratik penggunaanya. Dalam prosesitu siswa berinteraksi dengan komponen instrument pendidikan seperti guru, materi, media, sarana, dan metode mengajar.

Dapat diasumsikan, bahwa pendidikan merupakan salah satu kebutuhan yang sangat penting bagi seseorang, karena pendidikan yang baik akan dapat menentukan masa depannya. Oleh karena itu, untuk menunjang pendidikan pemerintah membentuk suatu lembaga formal yang menyelenggarakan pendidikan secara berencana, teroganisir, terarah dan sistematis. Akan tetapi sejauh efektivitas dalam mewujudkan masa depan peserta didik sangatlah ditentukan oleh komponen-komponen yang terlibat dalam proses pendidikan tersebut, salah satu komponen yang berperan penting adalah guru.

Salah satu masalah yang dihadapi dunia pendidikan adalah bagaimana usaha untuk meningkatkan proses pembelajaran sehingga memperoleh hasil yang efektif dan efesien. Pendidikan tidak hanya dilihat bagi perbaikan kinerja pendidikan sebagai salah satu instrument uatama pengembangan sumber daya manusia dengan multi kemampuan koginitif, efektif, dan psikomotorik. Berkaitan dengan hal tersebut perlu kiranya dilakukan upaya untuk meningkatkan proses pembelajaran yang lebih terpusat kepada siswa serta meningkatkan motivasi belajar yang akan memperbaiki hasil belajar siswa. Sudjana (Iskandar, 2009: 128) menyatakan, 
"hasil belajar merupakan suatu akibat dari proses belajar dengan menggunakan alat pengukuran, yaitu berupa tes yang disusun secara terencana, baik tes tertulis, tes lisan maupun tes perbuatan". Salah satu alternatif teknik pembelajaran yang dikembangkan untuk memenuhi aktivitas belajar dan tercapainya tujuan belajar siswa yakni pembelajaran yang terpusat pada siswa.

Dengan demikian penting kiranya dilakukan dengan memanfaatkan perpustakaan dalam proses pembelajaran. Baik itu memanfaatkan perpustakaan sebagai tempat sumber belajar dengan membaca, sebagai tempat mencari bahan-bahan belajar dalam menyelesaikan tugas, dan sebagai tempat berdiskusi (Mohamad, 2017). UU no. 43 Tahun 2007 Tentang Perpustakaan, (2010: 75) Bab I ketentuan umum pasal 1 perpustakaan adalah intuisi pengelola koleksi karya tulis, karya cetak, atau karya rekam secara profesional dengan sistem yang baku guna memenuhi kebutuhan pendidikan, penelitian, pelestarian, informasi dan rekreasi para pemustaka.

Perpustakaan adalah sarana penunjang di sekolah yang berupa kumpulan bahan pusaka, baik berupa buku-buku maupun bukan buku. Kumpulan bahan pustaka tersebut diorganisasi secara otomatis dalam suatu ruang sehingga dapat membantu murid-murid dan para guru dalam proses pembelajaran. Menurut Komalasari, K (2010:137) menyatakan, "perpustakaan sekolah merupakan unit kerja dan sebagai perangkat mutlak dari sekolah yang bersangkutan". Dengan tujuan menyediakan koleksi pustaka untuk menunjang keberhasilan proses belajar mengajar. Dikatakan juga bahwa perpustakaan tersebut merupakan jantungnya pelaksanaan pendidikan pada lembaga itu. Sedangkan fungsi utamanya yaitu sebagai pusat sumber belajar, pusat sumber informasi, pusat bacaan, rekreasi dan pengisi waktu senggang. Perpustakaan adalah sebagai tempat membina minat dan bakat para siswa menuju belajar sepanjang hayat.

Tujuan perpustakaan salah satunya agar siswa dan masyarakat sekolah yang lainnya dapat melakukan kegiatan-kegiatan positif dan produktif seperti, menemukan informasi, fakta, dan data yang belum diketahui, serta dapat berekreasi mencari dan mengali ilmu pengetahuan yang diperlukan dalam proses belajar mengajar. Dengan demikian dengan pemanfaatan perpustakaan sebagai sumber belajar diyakini dapat meningkatkan motivasi belajar siswa sehingga siswa dapat mengembangkan ilmu pengetahuan dan wawasan belajar. Sebagaimana yang dikemukakan oleh Siagan, (2006: 78) bahwa, motivasi adalah keseluruhan proses pemberian motive (dorongan) bekerja kepada bawahan sedemikian rupa sehingga 
mereka mau berkerja dengan iklas demi tercapainya tujuan organisasi/kelompok dengen efesien dan ekonomis. Menurut Gagne dan Berliner (Sutopo, 2007: 67) menyatakan bahwa,"motivasi adalah istilah yang menggambarkan upaya pemberian kekuatan (energizer) kepada seseorang untuk mengarahkan kegiatannya".

Merujuk pada tujuan perpustakaan sebagai tempat sumber belajar, sangat jelas bahwa tujuan pemanfaatan perpustakaan dalam menguatkan tujuan pada pembelajaran Pendidikan Pancasila dan Kewarganegaraan, yang mata pelajaran PPKn ini memfokuskan pada pembentukan warganegara yang memahami dan mampu melaksanakan hak-hak dan kewajibannya untuk menjadi warganegara Indonesia yang cerdas, terampil, dan berkarakter yang diamatkan oleh Pancasila dan UndangUndang Dasar (UUD 1945). Menurut Darmadi, H (2006:51) bahwa, "pendidikan moral menyangkut pembinaan sikap dan tingkah laku moral baik atau budi perkerti yang baik terutama dalam bidang tersebut". Dapat diasumsikan, bahwa dengan memanfaatkan perpsutakaan sebagai tempat literasi siswa pada proses pembelajaran diyakini dapat membangun generasi muda yang gemar membaca sehingga memiliki wawasan dan pengetahuan yang bertambah baik.

Asumsi diatas diperkuat oleh penelitian yang dilakukan oleh Nurul Mustividah, Teguh Pribadi \& Marni (2018) dengan judul; Kontribusi Pemanfaatan Perpustakaan Sekolah dan Motivasi Belajar Terhadap Peningkatan Hasil Belajar Siswa SMA. Hasil penelitian menyimpulkan bahwa, pemanfaatan perpustakaan sekolah dan motivasi belajar efektif meningkatkan hasil belajar geografi meskipun hasilnya kecil. Namun merujuk pada penelitian sebelumnya pada kontribusi pemanfaatan perpustakaan sekolah dan motivasi belajar terhadap peningkatan hasil belajar masih kecil, namun peran perpustakaan sebagai sumber belajar untuk meningkatkan motivasi siswa sangat dianjurkan untuk mendukung penelitian ini.

Berdasarkan data observasi, bahwa proses pembelajaran PPKn di SMA Negeri 1 Mentebah masih mengunakan model pembelajaran yang monoton yakni ceramah, kurangnya inisiatif guru untuk mendorong siswa memanfaatkan perpustakaan sebagai bahan sumber belajar dalam menyelesaikan tugas belajar, mengakibatkan kurangnya motivasi siswa untuk memanfaatkan perpustakaan. Dan minat membaca siswa diperpustakaan terlihat sangat rendah, mereka beranggapan bahwa kegiatan mengunjungi perpustakaan adalah kegiatan yang sangat membosankan, sehingga motivasi belajar siswa dengan memanfaatkan 
perpustakaan sekolah masih rendah. Untuk itu perlu kiranya upaya yang berkesinambungan dari guru PPKn bersama siswa untuk lebih mengefektifitaskan manfaat perpustakaan sebagai sumber belajar dengan menugaskan siswa untuk mencari bahan belajar di perpustakaan. Berdasarkan temuan observasi tersebut peneliti merasa penting meneliti tentang, "pemanfaatan perpustakaan dalam meningkatkan motivasi belajar siswa PPKn di SMA Negeri 1 Mentebah Kabupaten Kapuas Hulu, dan memfokuskan pada bagaimana motivasi belajar siswa kelas XI SMA Negeri 1 Mentebah dapat meningkat dengan guru memanfaatkan perpustakan sebagai sumber belajar.

\section{METODE PENELITIAN}

Penelitian ini menggunakan metode penelitian deskriptif dengan pendekatan kualitatif (Sugiyono, 2012). Metode kualitatif dalam penelitian ini ditunjukkan untuk memperoleh informasi yang berkenaan dengan Pemanfaatan Perpustakaan dalam Meningkatkan Motivasi Belajar Siswa pada Mata Pelajaran PPKn di Kelas XI SMA Negeri 1 Mentebah Kapuas Hulu.

Teknik pengumpulan data dalam penelitian ini, yaitu menggunakan teknik observasi langsung, teknik komunikasi langsung dan teknik studi dokumen. Teknik observasi langsung mengumpulkan data melalui pengamatan dan pencatatan gejala-gejala yang tampak pada obyek penelitian di perpustakaan SMA Negeri 1 Mentebah. Teknik ini menggunakan lembar observasi yang berkaitan dengan data kegiatan atau aktivitas siswa selama proses pembelajaran di perpustakaan. Teknik komunikasi langsung dalam penelitian ini mengumpulkan data dengan melakukan secara lisan atau tatap muka (face to face) dengan sumber data (Nawawi, H. 2012: 100). Teknik ini dilakukan pada kegiatan belajar siswa dan guru di perpustakaan, alat yang digunakan adalah pedoman wawancara. Teknik studi dokumen adalah teknik mengumpulkan data dengan melakukan klasifikasi bahan-bahan tertulis yang berhubungan dengan kegiatan belajar mengajar siswa selama diperpustakaan, adapun alat yang digunakan kamera.

Analisis data dilakukan dengan langkah-langkah yaitu: reduksi data, penyajian data, dan penarikan kesimpulan dengan model Milles and Humberman dalam (Sugiyono, 2012). Peneliti menggunakan triangulasi teknik pengumpul data dan triangulasi sumber data untuk menjamin kredibilitas dari kesimpulan hasil penelitian (Sugiyono, 2012). 
Penentuan subjek penelitian dilakukan secara purposive, yaitu dipilih berdasarkan pertimbangan tertentu, karena peneliti menganggap bahwa subjek tersebut dapat lebih dipercaya untuk menjadi sumber data. Sumber data yang dipilih juga mempertimbangkan beberapa persyaratan. Sebagaimana yang dikemukakan Faisal (Sugiyono, 2013:303) sampel sebagai sumber data atau informan sebaiknya memenuhi kriteria sebagai berikut:

1. Mereka menguasai atau memahami sesuatu melalui proses enkulturasi, sehingga itu bukan sekedar diketahui, tetapi juga dihayati.

2. Mereka yang tergolong masih sedang berkecimpung atau terlibat pada kegiatan yang tegah diteliti.

3. Mereka yang mempunyai waktu yang memadai untuk diminta informasi.

4. Mereka yang tidak cenderung menyampaikan informassi hasil "kemasannya" sendiri.

5. Mereka yang pada mulanya tergolong "cukup asing" dengan peneliti sehingga lebih menggarahkan untuk dijadikan semacam guru atau narasumber.

Subjek dalam penelitian ini yakni, 1 orang guru PPKn dan 5 orang siswa kelas XI, dan 1 orang teman sejawat guru PPKn, serta peneliti sendiri sebagai instrument dalam penelitian ini.

\section{HASIL DAN PEMBAHASAN}

\section{Motivasi Siswa Pada Mata Pelajaran PPKn di Kelas XI SMA Negeri 1 Mentebah Kabupaten Kapuas Hulu}

Motivasi merupakan suatu pendorong yang mengubah energi dalam diri seseorang ke dalam bentuk aktivitas nyata untuk mencapai tujuan tertentu. Seseorang yang melakukan aktivitas belajar secara terus menerus tanpa motivasi dari luar dirinya merupakan motivasi intrinsik yang sangat penting dalam aktivitas belajar. Namun, seseorang yang tidak mempunyai keinginan untuk belajar, dorongan dari luar dirinya merupakan motivasi ekstrensik yang diharapkan. Oleh karena itu, motivasi ekstrinsik diperlukan bila motivasi intrinsik tidak ada dalam diri seseorang sebagai subjek belajar. Guru-guru sangat menyadari pentingnya motivasi di dalam membimbing belajar peserta didik. Motivasi adalah pendorongan suatu usaha yang disadari untuk mempengaruhi tingkah laku seseorang agar ia tergerak hatinya untuk bertindak melakukan sesuatu sehingga mencapai hasil dan tujuan tertentu. Menurut Vroom (Purwanto, N. 2011: 72) 
"motivasi msengacu kepada suatu proses mempengaruhi pilihan-pilihan individu terhadap bermacam-macam bentuk kegiatan yang dikehendaki".

Jadi, dari pendapat di atas dapat diasumsikan bahwa, motivasi adalah suatu usaha yang disadari untuk menggerakkan, mengarahkan, dan menjaga tingkah laku seseorang agar ia terdorong untuk bertindak melakukan sesuatu sehingga mencapai hasil atau tujuan tertentu.

Berbagai macam teknik misalnya kenaikan tingkat, penghargaan, peranan-peranan kehormatan-kehormatan, piagam-piagam prestasi, pujian dan celaan telah digunakan untuk mendorong peserta didik agar mau belajar. Ada kalanya guru menggunakan teknik-teknik tersebut secara tidak tepat. Bukan hanya sekolah-sekolah yang berusaha memberi motivasi tingkah laku manusia ke arah perubahan tingkah laku yang diharapkan. Orang tua atau keluarga pun telah berusaha memotivasi belajar anak-anak mereka. Kelompok yang berkecimpung dibidang "manajement" yang membuat rencana "insentif" baru untuk meningkatkan, produksi adalah berusaha memotivasi perubahan dalam tingkah laku, yang diharapkan dalam hal ini adalah perubahan motivasi belajar siswa untuk memanfaatkan perpustakaan.

Dari hasil temuan penelitian di lapangan tentang Pemanfaatan Perpustakaan dalam Meninggkatkan Motivasi Belajar Siswa Pada Mata Pelajaran PPKn di Kelas XI SMA Negeri 1 Mentebah Kabupaten Kapuas Hulu, diperoleh data bahwa ternyata, perpustakaan merupakan sumber belajar yang diyakini dapat meningkatkan motivasi belajar siswa dan guru PPKn mempercayai bahwa memberikan latihan dan tugas dengan memanfaatkan perpustakaan sebagai sumber belajar dapat memberikan dorongan kepada siswa untuk membangun rasa percaya diri siswa sehingga siswa lebih termotivasi dan giat untuk belajar. Selanjutnya cara guru memotivasi belajar siswa yakni, dengan memberikan dukungan siswa agar bertanggungjawab atas kewajibannya dengan selalu memberikan arahan. Selain itu untuk meningkatkan motivasi belajar siswa guru selalu mengarahkan agar latihan dan tugas dikerjakan secara berkelompok secara dan dikerjakan di perpustakaan agar siswa mencari dan membaca beberapa referensi buku di perpustakaan. Karena guru PPKn berkeyakinan dengan selalu mengarahkan siswa untuk mengerjakan latihan dan tugas di perpustakaan dapat mempermudah siswa dalam menyelesaikan latihan dan tugas yang diberikan guru, sehingga diharapkan motivasi belajar siswa dengan memanfaatkan perpustakaan sekolah semakin meningkat.

Dari beberapa upaya yang dilakukan guru PPKn untuk meningkatkan motivasi belajar siswa dengan memanfaatkan perpustakaan tersebut sesuai 
dengan bunyi Undang-Undang Nomor 2 Tahun 1989 tentang Sistem Pendidikan Nasional Pasal 35 yang menjelaskan, "salah satu sumber belajar yang amat penting tetapi bukan satu-satunya adalah perpustakaan, yang harus memungkinkan para tenaga kependidikan dan para pesrta didik memperoleh kesempatan untuk memperluas dan koleksi lain yang diperlukan". Perpustakaan sekolah adalah koleksi kumpulan berbagai macam referensi kepustakaan yang diorganisasi dalam satu ruangan agar dapat digunakan oleh siswa dan guru. Diadakannya perpustakaan sekolah adalah untuk tujuan memenuhi kebutuhan informasi bagi masyarakat di lingkungan sekolah yang bersangkutan, khususnya para guru dan murid, ia berperan sebagai media dan sarana untuk menunjang kegiatan proses belajar menajar (PBM) ditingkat sekolah. Bafadal, I (2011: 4) menyatakan "Perpustakaan sekolah adalah kumpulan bahan pustaka, baik berupa buku, yan diorganisasikan secara sistematis dalam suatu ruang sehingga dapat membantu murid-murid dan guru-guru dalam proses pembelajaran di sekolah disebut perpustakaan sekolah".

Penelitian relevan yang dilakukan Anwar Mubarok (2014) dengan judul "Pemanfaatan Perpustakaan Sekolah Sebagai Sumber Belajar Seharah di Ma Nur Safinatul Huda Karimujawa Kabupaten Kepara". Hasil penelitian Mubarok (2014) menyimpulkan bahwa perpustakaan sekolah merupakan kumpulan bahan pustaka baik berupa buku-buku maupun bukan buku yang diorganisasikan secara sistematis dalam suatu ruang sehingga dapat membantu siswa dan guru dalam proses belajar mengajar karena sumber belajar adalah segala sesuatu yang dapat dimanfaatkan oleh guru maupun siswa dalam mempelajari materi, sehingga memudahkan siswa dalam memahami materi pelajaran. Dari hasil penelitian Anwar dapat menguatkan hasil penelitian ini, bahwa perpustakaan sekolah merupakan kumpulan bahan pustaka yang diyakini sebagai sumber belajar yang dapat mempermudah siswa dalam memahami materi pelajaran, sehingga diharapkan dengan mudah memahami materi pelajaran siswa semakin termotivasi dalam belajar PPKn.

Penelitian lain juga dilakukan oleh Risky Febriani (2014) dengan judul "Pemanfaatan Perpustakaan Sekolah Sebagai Sumber Belajar Siswa di SMP Negeri 3 Sungai Raya Kabupaten Kubu Raya". Hasil penelitian menunjukkan bahwa, pemanfaatan perpustakaan sekolah telah dilaukan dengan baik dilihat dari fungsi, pengelolaan dan frekuensi kehadiran siswa dari bulan juli hingga oktober sebesar $76 \%$ sehingga untuk lebih memaksimalkan pemanfaatan perpustakaan diharapkan adanya kerjasama natara guru, siswa dan pengelolaan perpustakaan. 
Dari hasil penelitian relevan tersebut dapat diasumsikan bahwa, pemanfaatan perpustakaan sebagai sumber belajar oleh siswa diyakini dapat meningkatkan minat maupun motivasi belajar siswa salah satunya siswa dapat dengan mudah dan terbantu dalam mengerjakan latihan dan tugas dari guru, sehingga dengan motivasi akan muncul minat baca siswa.

Dengan demikian relevansi hasil penelitian sebelumnya dengan judul penelitian ini memperkuat hasil tentang "Pemanfaatan perpustakaan dalam meningkatkan motivasi belajar siswa pada mata pelajaran PPKn di kelas XI SMA Negeri 1 Mentebah Kabupaten Kapuas Hulu" bahwa pemanfaatan perpustakaan sebagai sumber belajar untuk meningkatkan motivasi belajar siswa telah dilakukan oleh guru, dengan kemampuan dan pengetahuan yang guru miliki sehingga motivasi belajar siswa dengan memanfaatkan perpustakaan sekolah dapat terlihat peningkatannya, yakni; dari semangat belajar siswa dalam mengerjakan latihan dan tugas dari guru secara berkelompok dengan memanfaatkan sumber-sumber buku di perpustakaan sekolah. Karena diketahui sebelumnya motivasi belajar siswa kelas XI dengan memanfaatkan perpustakaan sebagai sumber belajar dalam mengerjakan tugas latihan dan tugas dari guru PPKn masih rendah, hal tersebut dibuktikan dengan masih rendahnya siswa kelas XI yang berkunjung ke perpustakaan.

Dari pembahasan di atas, dapat disimpulkan bahwa, motivasi belajar siswa pada mata pelajaran PPKn di kelas XI SMA Negeri 1 Mentebah Kabupaten Kapuas Hulu sudah terlihat bersemangat dalam mengerjakan latihan dan tugas yang diberikan guru, motivasi ekstrinsik yang muncul yakni, siswa mau berkunjung ke perpustakaan, siswa mau menggunakan sumber buku di perpustakaan dalam proses pembelajaran, siswa termotivasi untuk membaca sumber buku di perpustakaan sekolah, dan siswa termotivasi untuk meminjam buku di perpustakaan. Sedangkan untuk motivasi intrinsik yang muncul dalam diri siswa yakni; siswa termotivasi mengerjakan latihan dan tugas yang diberikan oleh guru secara berkelompok di perpustakaan sekolah, siswa juga termotivasi mengerjakan latihan dan tugas di rumah dengan sumber-sumber buku yang dipinjam dari perpustakaan sekolah, meskipun motivasi intrinsik belajar siswa masih pengaruhi oleh arahan dan perintah guru, namun setidaknya siswa sudah mulai tumbuh motivasi belajar dengan memanfaatkan perpustakaan. Adapun motivasi belajar siswa dengan memanfaatkan perpustakaan dapat dilihat pada Gambar 1 sebagai berikut : 


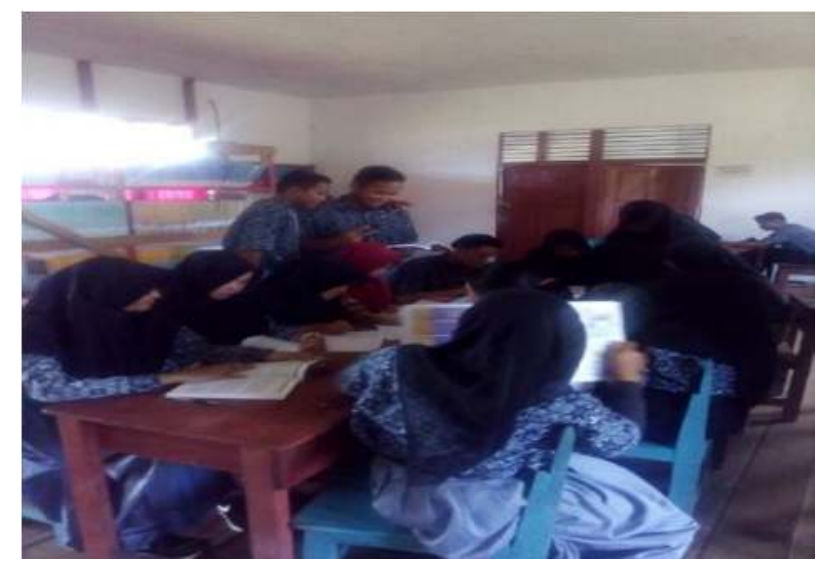

Gambar 1. Siswa mengerjakan tugas secara berkelompok di perpustakaan

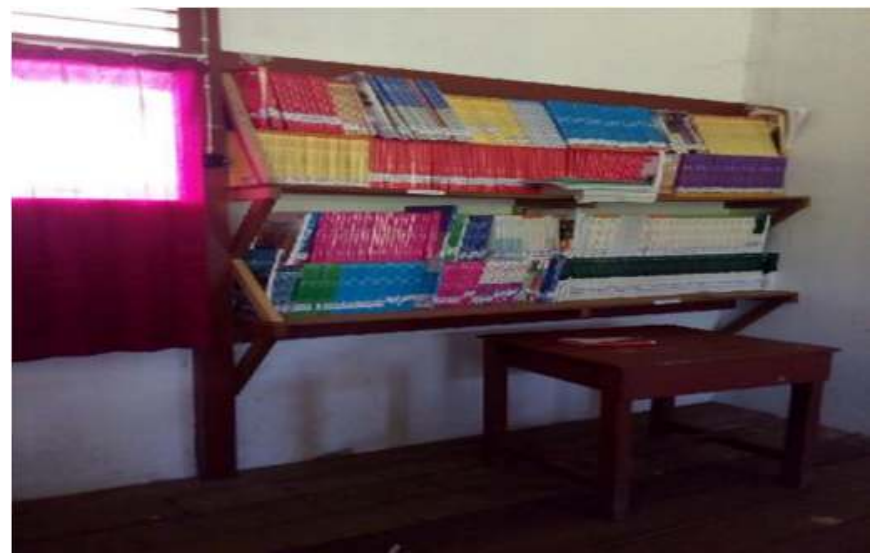

Gambar 2. Koleksi buku perpustakaan SMA N 1 Mentebah

\section{KESIMPULAN}

Berdasarkan hasil analisis yang dilakukan dapat disimpulkan bahwa, motivasi belajar siswa pada mata pelajaran PPKn di kelas XI SMA Negeri 1 Mentebah Kapuas Hulu cukup baik. Guru PPKn selalu merupaya memunculkan motivasi intrinsik dan ekstrinsik siswa. Motivasi intinsik yang muncul dari siswa kelas XI yakni; (a) siswa mau berkunjung ke perpustakaan (b) siswa menggunakan sumber buku di perpustakaan dalam proses pembelajaran (c) siswa termotivasi untuk membaca buku di perpustkaan dan (d) siswa termotivasi untuk meminjam buku di perpustakaan. Untuk motivasi intrinsik yang muncul yakni; (a) termotivasinya siswa mengerjakan latihan dan tugas yang diberikan guru di perpustakaan, maupun mengerjakan tugas di rumah dengan sumber balajar buku yang dipinjam dari perpustakaan. 


\section{UCAPAN TERIMAKASIH}

Peneliti mengucapkan terimakasih kepada guru-guru SMA Negeri 1 Mentebah yang telah turut membantu dan berpartisipasi dalam penelitian ini, sehingga penelitian ini dapat diselesaikan, dan terimakasih kepada peserta didik yang sudah turut aktif dalam pembelajaran PPKn dengan memanfaatkan perpustakaan sekolah sebagai sumber belajar.

\section{DAFTAR PUSTAKA}

Bafadal, I. (2011). Pengelola Perpustakaan Sekolah. Jakarta: Bumi Aksara

Darmadi, H. (2011). Pengantar Pendidikan Kewarganearaan. Bandung: Alfabeta.

Hamdani.(2011). Dasar-Dasar Kependidikan. Bandung: Pustaka Pelajar Iskandar. (2009). Psikologi Pendidikan (sebuah orientasi baru). Cipayung: Gaung Persada

Komalasari, K. (2010).Pembelajaran Kontekstual. Jakarta: Bumi Aksara.

Mohamad, L. A. P. (2017) Pemanfaatan Perpustakaan sebagai Sumber Belajar untuk Meningkatkan Minat Baca Siswa di Perpustakaan Kota Magelang. http://journal.student.uny.ac.id/ojs/index.php Vol VI, Nomor 4, Tahun 2017. [ diacces 4 Maret 2020].

Mubarok, A. (2014). Pemanfaatan Perpustakaan sekolah Sebagai Sumber Belajar Sejarah di MAN Nu Safinatul Huda Karimun Jawa Kabupaten Jepara. Jurnal Ilmu Informasi Perpustakaan dan Kearsipan, 13 (6): C 101140.

Nurul, M, Teguh, P \& Marni. (2018). Kontribusi Pemanfaatan Perpustakaan Sekolah dan Motivasi Belajar Terhadap Peningkatan Hasil Belajar Geografi Siswa SMA. http://journak2.um.ac.id/index.php/jpg/ ISSN: 0853-9251 (p) and 2527-628X (e). [diacces 4 Maret 2020].

Nawawi, H. (2012). Metode Penelitian Bidang Sosial. Yogyakarta: Gajah Mada University Pers.

Purwanto.(2008). Evaluasi Hasil Belajar. Yogyakarta: PustakaPelajar.

Risky, Febriani. (2014) Pemanfaatan Perpustakaan Sekolah Sebagai Sumber Belajar Siswa di SMP Negeri 3 Sungai Raya Kabupaten Kubu Raya. http://jurnal.untan.ac.id/index.php/jpdpb/article/view Vol 3, No 2 (2014) [diakses 4 Maret 2020].

Sugiyono. (2012). Metode Penelitian Kuantitatif, Kualitatif, dan RED. Bandung: Alfabeta.

Siagan. (2006). Guru dan Anak Didik Dalam Interaksi Edukatif. Jakarta: PT. Raja Grafindo.

Sutopo.(2007). Evaluasi Pembelajaran. Jakarta: Rieneka Cipta. 
Undang-Undang Republik Indonesia Nomor 43 Tentang Perpustakaan 2007.

Undang-Undang Nomor 2 Tahun 1989 tentang Sistem Pendidikan Nasional Pasal 35. 